\title{
Mechanism of liquefaction of the human ejaculate I. Changes of the ejaculate proteins
}

\author{
E. Koren and J. Lukač \\ Laboratory for Experimental Medicine, Faculty of Pharmacy and Biochemistry, University of \\ Zagreb, Domagojeva 2,41000 Zagreb, Yugoslavia
}

\begin{abstract}
Summary. The spontaneous liquefaction of the human ejaculate in vitro was studied by macroscopic inspection, disc electrophoresis of the ejaculate proteins, free amino acid and nitrogen determinations and by electron microscopy. Liquefaction occurred in three phases. Phase 1 was characterized by the macroscopic solubilization of the gelatinous material and by disappearance of its granular ultrastructure. $\mathrm{Zn}^{++}, \mathrm{Hg}^{++}$and $\mathrm{Cu}^{++}$completely inhibited the first step of the liquefaction, which could be reversed by $\mathrm{Na}_{2}$ EDTA. The factor(s) involved is most probably a proteolytic enzyme(s) which is tightly incorporated into the gelatinous material. In Phase 2 of liquefaction solubilized proteins were degraded to peptides and in Phase 3 these peptides were degraded to amino acids. Factor(s) responsible for these two steps of liquefaction could be removed by washing the gelatinous material.
\end{abstract}

\section{Introduction}

The human ejaculate, like that of many other mammals, becomes gelatinous when emitted. The coagulation of the ejaculate is believed to be due to the action of a prostatic 'clotting enzyme' on a protein material derived from the seminal vesicles (Mann, 1964). At room temperature the human ejaculate liquefies macroscopically within 10 to 20 min after ejaculation (Amelar, 1962; Mann, 1964).

It is believed that the human ejaculate liquefies because of the proteolytic degradation of the proteins in the coagulum, and a two-step mechanism of the liquefaction has been suggested. The first step would be the so-called 'fibrinolysis', i.e. splitting of the fibrin-like protein, and the second would be further proteolysis of the lysed fibrin-like protein, leading to the release of free amino acids and ammonia (Lundquist, Thorsteinsson \& Buus, 1955; Mann, 1964). However, the two-step mechanism of liquefaction is not based on direct experimental evidence, and the fibrinlike nature of human ejaculate proteins has not been proved.

In this work, the sequence and the nature of the morphological and biochemical changes of human ejaculate proteins during the process of liquefaction were studied.

\section{Materials and Methods}

Human semen was obtained from fertile volunteers, 25-40 years old, by manual masturbation. Only specimens of optimal quality were used, i.e. with a sperm count of about $10^{8} / \mathrm{ml},<25 \%$ immotile spermatozoa, and $<30 \%$ abnormal forms.

\section{Liquefaction}

The liquefaction mechanism was studied by observing macroscopic, ultrastructural and chemical changes in (a) the intact ejaculate, (b) the frozen ejaculate, (c) the washed-frozen ejaculate and (d) the 'recoagulum'. 
The intact ejaculate. Immediately after collection of the ejaculate into $2 \mathrm{ml} 0.05 \mathrm{M}$ Trisacetate buffer, $\mathrm{pH} 7.5$, containing $0.05 \mathrm{M}-\mathrm{NaCl}$, the mixture was placed into a water bath at $37^{\circ} \mathrm{C}$ and observed for $6 \mathrm{~h}$. From each specimen a small piece (100-200 mg) of ejaculate was taken at various times ( $30 \mathrm{sec}, 1,2,3,5$ and $12 \mathrm{~min}$ ) after ejaculation and transferred into $2 \mathrm{ml}$ $2 \%$ glutaraldehyde. After fixation for $1 \mathrm{~h}$ in glutaraldehyde these samples were examined by electron microscopy. From each incubation mixture (ejaculate $+2 \mathrm{ml}$ buffer), $15 \mu \mathrm{l}$ aliquots of the liquid phase were also taken for disc electrophoresis at $30 \mathrm{sec}, 15$ and $30 \mathrm{~min}$, and 3 and $6 \mathrm{~h}$ after ejaculation.

The frozen ejaculate. The ejaculate was collected into small glass tubes containing $2 \mathrm{ml}$ icecold buffer $(\mathrm{pH} 7.5)$ and immediately frozen at $-20^{\circ} \mathrm{C}$. The frozen ejaculate was then cut and weighed. Pieces averaging $800 \mathrm{mg}$ were transferred into $0.8 \mathrm{ml}$ aliquots of the Tris-acetate buffer $(\mathrm{pH} 7.5)$ or into $0.8 \mathrm{ml}$ aliquots of buffered solutions of metals $\left(\mathrm{Hg}^{++}, \mathrm{Zn}^{++}, \mathrm{Cu}^{++}\right)$or into the buffered solutions of a chelating agent ( $\left.\mathrm{Na}_{2} \mathrm{EDTA}\right)$. The whole procedure was always performed at $0^{\circ} \mathrm{C}$. The divided ejaculate portions in the respective buffers were then placed into the water bath $\left(37^{\circ} \mathrm{C}\right)$ and changes in each sample were observed macroscopically, by electron microscopy, disc electrophoresis and amino acid analysis during the next $6 \mathrm{~h}$ of incubation.

The washed-frozen ejaculate. Semen was collected and frozen as described above. The frozen ejaculate was transferred into $100 \mathrm{ml}$ ice-cold Tris-acetate buffer (pH 7.5). After thawing, the ejaculate (which does not liquefy at $0^{\circ} \mathrm{C}$ ) was separated by centrifugation ( $3 \mathrm{~min}$, $700 \mathrm{~g}, 0^{\circ} \mathrm{C}$ ) and the buffer was discarded. This procedure was repeated four times. After the last centrifugation the washed ejaculate was transferred into $2 \mathrm{ml}$ of the same buffer and frozen at $-20^{\circ} \mathrm{C}$. The liquefaction of the washed-frozen ejaculate was then studied in the same way as the frozen ejaculate.

The 'recoagulum'. The washed-frozen ejaculate, prepared as described above, was thawed and mixed with $4 \mathrm{ml}$ ice-cold $0.05 \mathrm{M}$-Tris-acetate buffer, $\mathrm{pH} 4.0$, containing $0.05 \mathrm{M}-\mathrm{NaCl}$. At this $\mathrm{pH}$ the ejaculate turned into an opalescent liquid within $30 \mathrm{sec}$ and was then centrifuged (10 min, $500 \mathrm{~g}, 0^{\circ} \mathrm{C}$ ). The supernatant was separated from the sedimented spermatozoa and other cells and its $\mathrm{pH}$ was adjusted to 7.5 by the addition of $1 \mathrm{M}$-Tris buffer $(60 \mu \mathrm{l} 1 \mathrm{M}$-Tris/ml supernatant). At $\mathrm{pH} 7.5$ the supernatant recoagulated instantly. The recoagulated material, arbitrarily called 'recoagulum', was then washed three times with $10 \mathrm{ml}$ ice-cold Tris-acetate buffer, $\mathrm{pH} 7 \cdot 5$, and frozen at $-20^{\circ} \mathrm{C}$. The liquefaction of the 'recoagulum' was studied by the same procedure as the frozen and washed-frozen ejaculate materials.

\section{Determination of glycine and nitrogen}

Glycine was determined according to the method of Watermann, Barkhout \& Bos (1947). The $100 \mu \mathrm{l}$ aliquots of ejaculate were taken at various times during liquefaction and mixed with $0.9 \mathrm{ml} 5 \%$ trichloracetic acid. After $3 \mathrm{~h}$ the samples were passed through Whatman filter paper No. 1 and free amino acids were determined in filtrates. Nitrogen was determined by the method of Miller \& Houghton (1945).

\section{Electron microscopy}

During incubation of the intact coagulated ejaculate, small pieces of undissolved material were removed from the incubation mixture and fixed for $1 \mathrm{~h}$ in $5 \%$ glutaraldehyde. After fixation in glutaraldehyde the samples were transferred into $1 \% \mathrm{OsO}_{4}$ solution and $2 \mathrm{~h}$ later the samples were dehydrated in acetone and embedded in durcopan ACM resin. The sections, cut with an LKB ultramicrotome, were double stained with uranyl acetate and lead citrate, and viewed in an Opton M-9 Zeiss electron microscope.

\section{Disc electrophoresis}

Polyacrylamide gel electrophoresis was performed by the method of Reisfeld, Lewis \& Williams (1962) on $7.5 \%$ polyacrylamide gels at $\mathrm{pH} 8 \cdot 3$. The intensity of protein fractions was 
measured by a Kipp \& Zonen (Holland) DD2 densitometer and BC1 digital integrator. Equivalent volumes of material were applied to each gel since the protein concentrations of the different ejaculates were similar $(30-40 \mathrm{mg} / \mathrm{ml})$. The changes were followed for each particular ejaculate and were consistent.

\section{Intact ejaculate}

\section{Results}

First phase. The liquefaction of the intact ejaculate was completed macroscopically within 10 to $15 \mathrm{~min}(10.6 \pm 1.08$ (s.e.m.), 11 samples). Electron microscopy revealed that the ejaculate consisted, immediately after ejaculation, of spherical particles $100-500 \mathrm{~nm}$ in diameter surrounding the spermatozoa. During macroscopically visible liquefaction these particles were transformed into a homogeneous mass within the first $3 \mathrm{~min}$ (Pl. 1, Figs 1 and 2). No significant changes in the shape, size and substructure of spermatozoa were noticed. After liquefaction had been completed macroscopically, 11 distinct protein fractions were distinguished on the disc electropherograms of the resulting seminal plasma (Pl. 2, Fig. 4B).

Second phase. During the next $3 \mathrm{~h}$ of incubation the electrophoretic pattern of the seminal plasma proteins underwent significant changes: some protein bands stained less densely (a, $b, e$, $\mathrm{f}, \mathrm{g}, \mathrm{h}$ and $\mathrm{i}$ ), others became more dense (o, d, j, k, m; Pl. 2, Fig. 4C; Table 1). No significant changes in the electropherograms could be noted after the end of this period (Pl. 2, Fig. 4D). Even after $18 \mathrm{~h}$ of incubation the electrophoretic pattern was apparently unchanged in comparison to that of the gel D in Pl. 2, Fig. 4.

Third phase. This phase began at about $180 \mathrm{~min}$ and was characterized by an increase of the free glycine concentration in the incubation mixture (Table 2).

Table 1. Densitometric changes (as \% of total densitometric intensity) of the protein bands in the intact human ejaculate at different times during liquefaction

\begin{tabular}{cccc}
\hline & \multicolumn{3}{c}{ Time of incubation at $37^{\circ} \mathrm{C}$} \\
\cline { 2 - 4 } $\begin{array}{c}\text { Protein } \\
\text { band }\end{array}$ & $14 \mathrm{~min}($ Gel B) & $3 \mathrm{~h}($ Gel C) & $6 \mathrm{~h}(\mathrm{Gel} \mathrm{D})$ \\
\hline $\mathrm{o}$ & 2.91 & 6.32 & 7.21 \\
$\mathrm{a}$ & 12.07 & 11.63 & 13.08 \\
$\mathrm{~b}$ & 15.02 & 7.88 & 8.64 \\
$\mathrm{c}$ & 10.96 & 10.59 & 11.36 \\
$\mathrm{~d}$ & 3.90 & 19.23 & 20.12 \\
$\mathrm{e}$ & 14.46 & 13.95 & 12.37 \\
$\mathrm{f}$ & 10.88 & 6.59 & 6.46 \\
$\mathrm{~g}$ & 15.46 & 9.75 & 6.45 \\
$\mathrm{~h}$ & 8.60 & 5.38 & 4.73 \\
$\mathrm{i}$ & 1.60 & 0 & 0 \\
$\mathrm{j}$ & 4.14 & 6.32 & 7.69 \\
$\mathrm{k}$ & 0 & 0.28 & 0.35 \\
$\mathrm{~m}$ & 0 & 2.08 & 1.54 \\
\hline
\end{tabular}

\section{Frozen ejaculate}

First phase. The frozen ejaculate liquefied macroscopically within 25 to $42 \mathrm{~min}(34.0 \pm 6 \cdot 6$, s.e.m., 16 samples). During this step, electron microscopy revealed changes in the ejaculate similar to those described above, i.e. the spherical particles (100-500 nm diam.) surrounding the spermatozoa became transformed into a homogeneous mass. The only difference was noted in the time required because the granular substructure disappeared within $5 \mathrm{~min}$.

Second phase. After liquefaction of the frozen ejaculate had been completed macroscopically, the proteins which appeared were identical to those of the intact ejaculate (Pl. 2, Fig. 4E). 
Table 2. Concentrations (mean \pm s.e.m. for 4 estimations) of free glycine released during the incubation of intact, frozen and washed-frozen human ejaculates at $37^{\circ} \mathrm{C}$ and $\mathrm{pH} 7.5$

\begin{tabular}{|c|c|c|c|}
\hline \multirow{2}{*}{$\begin{array}{l}\text { Time of } \\
\text { incubation } \\
\text { (min) }\end{array}$} & \multicolumn{3}{|c|}{ Free glycine ( $\mu \mathrm{g} / \mathrm{mg}$ nitrogen) } \\
\hline & $\begin{array}{c}\text { Intact } \\
\text { ejaculate }\end{array}$ & $\begin{array}{c}\text { Frozen } \\
\text { ejaculate }\end{array}$ & $\begin{array}{l}\text { Washed-frozen } \\
\text { ejaculate }\end{array}$ \\
\hline 0 & $148 \cdot 3 \pm 10.9$ & $85.5 \pm 9.9$ & $68 \cdot 1 \pm 5 \cdot 9$ \\
\hline 5 & $151.9 \pm 18.1$ & $91.0 \pm 10.7$ & $96.3 \pm 6.6$ \\
\hline 15 & $139.1 \pm 16.6$ & $108 \cdot 5 \pm 12.4$ & $72.9 \pm 9.1$ \\
\hline 40 & $112 \cdot 1 \pm 8 \cdot 7$ & $109 \cdot 2 \pm 8 \cdot 9$ & $93.6 \pm 8.9$ \\
\hline 90 & $129.9 \pm 10 \cdot 1$ & $135 \cdot 1 \pm 15 \cdot 2$ & $98 \cdot 1 \pm 12.6$ \\
\hline 120 & $149 \cdot 1 \pm 15 \cdot 8$ & $145 \cdot 3 \pm 11 \cdot 1$ & $90.9 \pm 11.8$ \\
\hline 180 & $264.4 \pm 30 \cdot 2$ & $252.6 \pm 21.8$ & $112.9 \pm 14.4$ \\
\hline 300 & $371 \cdot 3 \pm 39 \cdot 3$ & $356.9 \pm 27.3$ & $131.4 \pm 10.8$ \\
\hline
\end{tabular}

Third phase. Further changes in the electrophoretic pattern and concentration of glycine were also identical to those in the intact ejaculate (Pl. 2, Fig. 4F; Table 2).

The liquefaction of the frozen ejaculate was influenced by some metal ions $\left(\mathrm{Hg}^{++}, \mathrm{Cu}^{++}\right.$, $\mathrm{Zn}^{++}$) which completely inhibited the first phase, i.e. macroscopically visible lysis (Table 3). No protein fractions could be obtained on disc electropherograms (Pl. 2, Fig. 5). On the other hand, in the presence of $\mathrm{Na}_{2}$ EDTA the first phase of liquefaction was accelerated and the inhibitory effect of metal ions was completely reversed (Pl. 2, Fig. 5; Table 3).

Table 3. The effect of metallic cations and $\mathrm{Na}_{2}$ EDTA on the duration of the first phase of liquefaction of the human frozen ejaculate at $37^{\circ} \mathrm{C}$ and $\mathrm{pH} 7.5$

\begin{tabular}{lclc}
\hline $\begin{array}{c}\text { Agent } \\
\text { added* }\end{array}$ & $\begin{array}{c}\text { Conc. of agent } \\
(\mathrm{M})\end{array}$ & $\begin{array}{c}\text { Time to end of } \\
\text { first phase of } \\
\text { liquefaction (min) }\end{array}$ & $\begin{array}{c}\text { No. of } \\
\text { experiments }\end{array}$ \\
\hline- & - & $34 \cdot 0 \pm 6 \cdot 6$ & 16 \\
$\mathrm{Hg}^{++}$ & $10^{-3}$ & No liquefaction & 13 \\
$\mathrm{Zn}^{++}$ & $10^{-3}$ & No liquefaction & 13 \\
$\mathrm{Cu}^{++}$ & $10^{-3}$ & No liquefaction & 5 \\
$\mathrm{Na}_{2}$ EDTA & $10^{-3}$ & $21 \cdot 0 \pm 1 \cdot 8$ & 11 \\
& $5 \times 10^{-3}$ & $12 \cdot 0 \pm 1.6$ & 6 \\
& $10^{-2}$ & $5 \cdot 0 \pm 0.8$ & 5 \\
\hline
\end{tabular}

* All metal salts were in chloride form.

\section{PLATE 1}

Fig. 1. Electron micrograph of the intact coagulated ejaculate immediately after ejaculation. Spherical particles (SP), 100-500 $\mathrm{nm}$, can be seen surrounding spermatozoa. $\mathrm{H}=$ sperm head; $\mathrm{T}=$ sperm tail. $\times 17500$.

Fig. 2. Electron micrograph of the intact ejaculate after $3 \mathrm{~min}$ of liquefaction at $37^{\circ} \mathrm{C}$. The spherical particles have become transformed into a homogeneous mass (HM) although macroscopically the ejaculate still appears gelatinous. $\mathrm{H}=$ sperm head; $\mathrm{T}=$ sperm tail. $\times 17500$.

Fig. 3. Electron micrograph of the "recoagulum". Spherical particles (SP) similar to those in the intact coagulated ejaculate (Fig. 1) are visible. No spermatozoa or other cells were found. $\times 17500$. 
PLATE 1
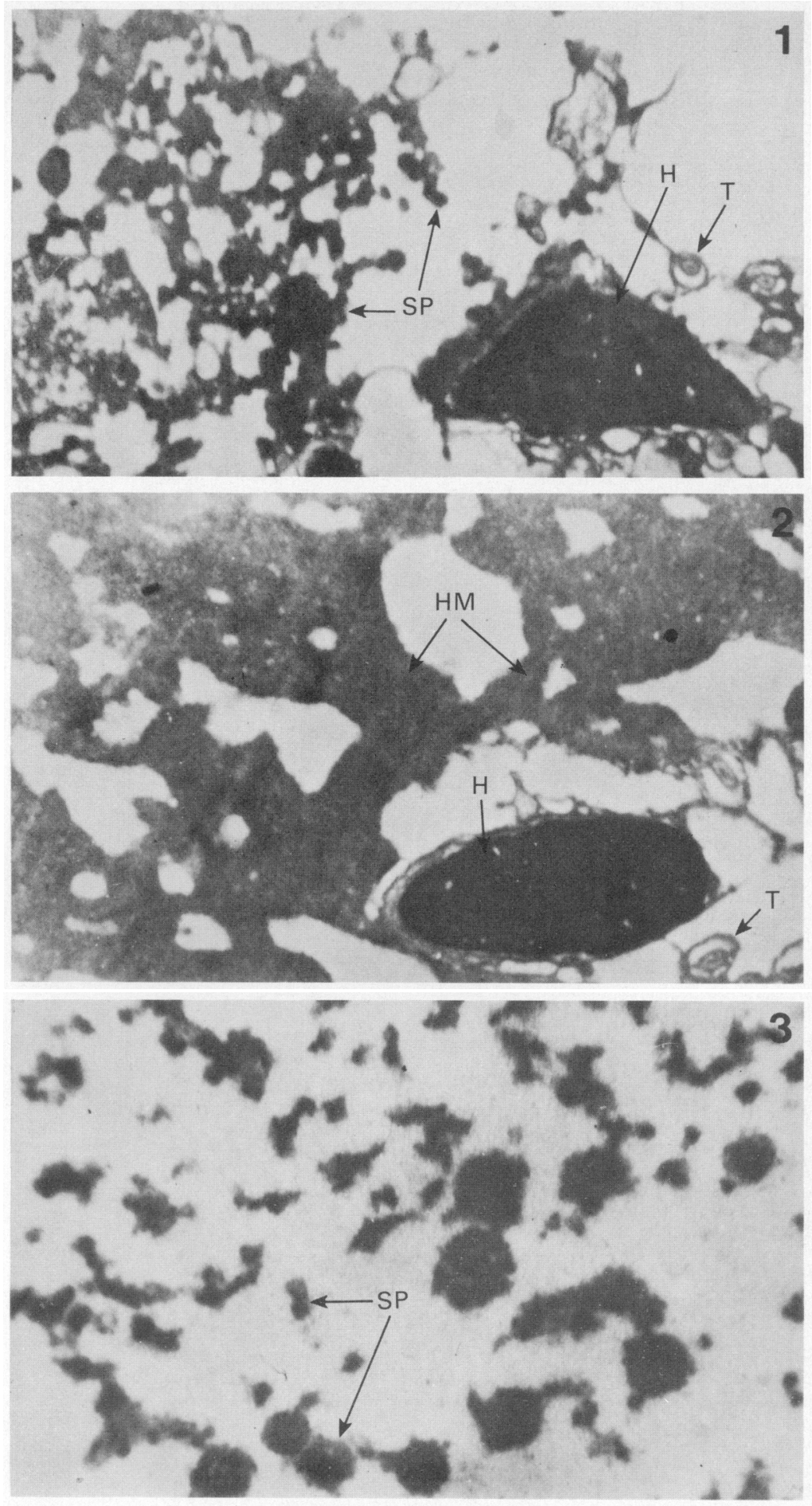

(Facing p. 496) 


\section{Washed-frozen ejaculate}

First phase. The first phase of liquefaction lasted for $36.8 \pm 8.7 \mathrm{~min}$ (16 samples) and by the end the same protein bands had appeared (Pl. 2, Fig. 4G).

Second phase. The changes in the electrophoretic pattern during the next $3 \mathrm{~h}$ of incubation differed from these of the intact and frozen ejaculates and were primarily associated with bands $\mathrm{e}-\mathrm{i}$ which did not decrease in density (Pl. 2, Fig. 4H).

Third phase. Table 2 shows that the release of free glycine was significantly retarded.

\section{'Recoagulum'}

First phase. The 'recoagulum' did not liquefy macroscopically even after $6 \mathrm{~h}$ of incubation. Electron microscopy showed that the globular substructure of the 'recoagulum' was unchanged even after $3 \mathrm{~h}$ of incubation (Pl. 1, Fig. 3).

Second and third phases. The events typical of these phases did not occur as a consequence of lack of change in the first phase. Disc electrophoresis of the incubation mixture liquid phase did not demonstrate any of the above proteins at 1,3 or $6 \mathrm{~h}$ of incubation, and no free glycine was detected.

\section{Discussion}

According to the results presented in this work we suggest a three-step mechanism of liquefaction of the human ejaculate in vitro. The first phase would comprise the well known macroscopically visible solubilization of the gelatinous ejaculate. With the intact ejaculate, the first phase of liquefaction was completed within about $11 \mathrm{~min}$ and is in accordance with data reported by Huggins \& Neal (1942) and Amelar (1962). However, the duration of the first phase of liquefaction was significantly influenced by freeze-thawing, metal ions and $\mathrm{Na}_{2} \mathrm{EDTA}$. The

\section{PLATE 2}

Fig. 4. Disc electropherograms of human ejaculates incubated at $37^{\circ} \mathrm{C}$ and $\mathrm{pH} 7 \cdot 5$. (A) Intact ejaculate immediately after ejaculation. (B) Intact ejaculate after 14 min of incubation, i.e. at the end of the first phase. Eleven distinct protein fractions are visible $(\mathrm{o}-\mathrm{j}) .(\mathbf{C})$ Intact ejaculate after $3 \mathrm{~h}$ of incubation, i.e. at the end of the second phase. Two fast migrating fractions $(\mathrm{k}, \mathrm{m})$ have appeared, the intensity of fractions $o, d$ and $j$ have increased and the intensity of fractions $a, b, c$, $\mathrm{f}, \mathrm{g}, \mathrm{h}$ and $\mathrm{i}$ has decreased. (D) Intact ejaculate after $6 \mathrm{~h}$ of incubation. No further changes are visible. (E) Frozen ejaculate after $39 \mathrm{~min}$ of incubation, i.e. at the end of the first phase. Eleven protein fractions identical to those in the intact ejaculate (gel B) are visible. (F) Frozen ejaculate after $3 \mathrm{~h}$ of incubation, i.e. at the end of the second phase. The electrophoretic pattern of the protein fractions is almost identical to that of the intact ejaculate after $3 \mathrm{~h}$ of incubation (C). (G) Washed-frozen ejaculate after $42 \mathrm{~min}$ of incubation, i.e. at the end of the first phase. Fractions $\mathrm{o}, \mathrm{a}, \mathrm{b}, \mathrm{c}, \mathrm{d}, \mathrm{g}, \mathrm{h}$, and $\mathrm{j}$ are of the same intensity, fractions $\mathrm{e}$ and $\mathrm{f}$ are decreased while fractions $\mathrm{i}$ and $m$ are increased in comparison with those in the intact ejaculate (gel B). (H) Washed-frozen ejaculate after $3 \mathrm{~h}$ of incubation. All fractions were apparently unchanged in comparison with those found at the end of the first phase of liquefaction (gel G).

Fig. 5. Disc electropherograms of the frozen ejaculate incubated at $37^{\circ} \mathrm{C}$ and $\mathrm{pH} 7 \cdot 5$. (A) After $3 \mathrm{~h}$ of incubation in $1 \mathrm{~mm}-\mathrm{HgCl}_{2}$ solution. (B) After $3 \mathrm{~h}$ of incubation in $1 \mathrm{~mm}-\mathrm{ZnCl}_{2}$ solution. (C) After $3 \mathrm{~h}$ of incubation in $1 \mathrm{~mm}-\mathrm{CuCl}_{2}$ solution. (D) After $3 \mathrm{~h}$ of incubation in $1 \mathrm{~mm}-\mathrm{ZnCl}_{2}$ solution and subsequent addition of $5 \mathrm{mM}-\mathrm{Na}_{2}$ EDTA. No liquefaction of the ejaculate took place in $\mathrm{Hg}^{++}, \mathrm{Zn}^{++}$and $\mathrm{Cu}^{++}$solutions and characteristic protein bands did not appear (gels $\mathrm{A}, \mathrm{B}$, C). After addition of $\mathrm{Na}_{2}$ EDTA the ejaculate liquefied within $40 \mathrm{~min}$. In this case (gel D) the number and distribution of protein fractions correspond to those obtained after the first phase of liquefaction of the intact ejaculate (see Fig. 4, gel B). 
inhibition of the first step by $\mathrm{Hg}^{++}, \mathrm{Cu}^{++}$and $\mathrm{Zn}^{++}$would confirm protease action in this process (Lundquist, 1952; Lundquist et al., 1955), since heavy metals are known to be - $\mathrm{SH}$ blocking agents, i.e. enzyme inhibitors (Boyer, 1959; Arnon, 1970). The promoting influence of the chelating agent $\mathrm{Na}_{2}$ EDTA on the first step of liquefaction could be taken as additional evidence in favour of the above assumption. The human ejaculate normally contains a high concentration of zinc and citrate (chelating) ions (Huggins \& Neal, 1942; Bernstein, 1958; Lindholmer \& Eliasson, 1974a, b), and maintenance of these agents within physiological limits would be necessary for normal ejaculate liquefaction.

The globular substructure of the human ejaculate protein material, when coagulated, shows that the ejaculate does not have a fibrin-like nature (Lundquist, 1952; Mann, 1964), because fibrin is characterized by a fibrillar substructure (Beck, Furlan, Seelich \& Williger, 1977). Although the time of liquefaction was prolonged for frozen and washed-frozen ejaculates, the globular substructure of the ejaculate was unchanged in comparison with that of the intact ejaculate. Moreover, the globular substructure was re-established in the recoagulation experiment, indicating a minor (if any) role of spermatozoa in the gelatinous consistency of the ejaculate. However, spermatozoa with their proteolytic enzymes could be important for the disappearance of the globular structure, since the 'recoagulum', i.e. sperm-deprived ejaculate, did not liquefy.

The second phase of the liquefaction comprises further degradation of the specific proteins (bands e, $f, g, h$ ) solubilized during the first phase. The electrophoretic pattern of the washedfrozen ejaculate proteins was, after Phase 1, very similar to those of the intact and frozen ejaculates. This means that the proteins found after the first phase of liquefaction originate from the globules, since in the ejaculate-washing experiment any other source of proteins was removed. The second phase of liquefaction of the intact and frozen ejaculate was completed within $3 \mathrm{~h}$, while this step was prolonged to at least $6 \mathrm{~h}$ for washed-frozen ejaculates. Obviously most of the factor or factors responsible for the second phase can easily be removed from the ejaculate by simple washing.

The third phase of liquefaction starts during the third hour of incubation and is characterized by higher concentrations of free glycine.

The electrophoretic pattern analyses suggest that only a small part of the ejaculate proteins undergo total degradation to free amino acids, since most of the electrophoretic fractions (b, c, d, $\mathrm{e}, \mathrm{f}, \mathrm{h}, \mathrm{j}$ ) remained unchanged even after $18 \mathrm{~h}$ of incubation. These data show that proteolysis to amino acids and ammonia during ejaculate liquefaction is probably not complete (Mann, 1964; Lundquist et al., 1955).

This work was supported by research grant No. 760-0324 from the Ford Foundation, New York, N.Y., and by Self-managing Authority for Scientific Research of SR Croatia.

\section{References}

Amelar, R.D. (1962) Coagulation, liquefaction and viscosity of human semen. J. Urol. 87, 187-190.

Arnon, R. (1970) Cysteine proteases. In Methods in Enzymology, Vol. XIX, pp. 226-273. Eds S. P. Colowick \& N. O. Kaplan. Academic Press, New York.

Beck, E.A., Furlan, M., Seelich, T. \& Williger, W. (1977) Molecular aspects of fibrinogen-fibrin transition. In New Methods for the Analysis of Coagulation using Chromogenic Substrates, pp. 3-18. Ed. I. Witt. Walter de Gruyter, Berlin.

Bernstein, G. S. (1958) Effect of ethylenediamine tetracetic acid (versene) on motility, oxygen con- sumption and anaerobic fructolysis of human sperm. Fert. Steril. 9, 120-133.

Boyer, P.D. (1959) Sulphydryl and disulphide groups of enzymes. In The Enzymes, Vol. 1, pp. 512-586. Eds. P. D. Boyer, H. Lardy \& K. Myrbäck. Academic Press, New York.

Huggins, C. \& Neal, W. (1942) Coagulation and liquefaction of semen. Proteolytic enzymes and citrate in prostatic fluid. J. exp. Med. 76, 527-541.

Lindholmer, Ch. \& Eliasson, R. (1974a) Zinc and magnesium in human spermatozoa from different fractions of split ejaculates. Int. J. Fert. 19, 4548. 
Lindholmer, Ch. \& Eliasson, R. (1974b) In vitro release and uptake of zinc and magnesium by human spermatozoa. Int. J. Fert. 19, 56-62.

Lundquist, F. (1952) Studies on the biochemistry of human semen. IV. Amino acids and proteolytic enzymes. Acta physiol. scand. 25, 178-187.

Lundquist, F., Thorsteingson, Th. \& Buus, O. (1955) Purification and properties of some enzymes in human seminal plasma. Biochem. J. 59, 69-79.

Mann, T. (1964) The Biochemistry of Semen and of the Male Reproductive Tract. Methuen, London.
Miller, L. \& Houghton, J. A. (1945) The micro-Kjeldhal determination of the nitrogen content of amino acids and proteins. J. biol. Chem. 159, 373-383.

Reisfeld, R.A., Lewis, V. J. \& Williams, D.E. (1962) Disc electrophoresis of basic proteins and polypeptides on polyacrylamide gels. Nature, Lond. 195, 281-290.

Watermann, N., Barkhout, H.W. \& Bos, C. J. (1947) Bestimmung von Glykokoll. In Medizinische Chemie, pp. 820-821. Eds K. Hinsberg \& K. Lang. Urban und Schwarzenberg, München.

Received 25 September 1978 